\title{
Distribution of Vibrio species in Shellfish and Water Samples Collected from the Atlantic Coastline of South-East Nigeria
}

\author{
Onyedikachukwu A.L. Eyisi, Uchechukwu U. Nwodo, Christian U. Iroegbu \\ Epidemiological Research Unit, Department of Microbiology, University of Nigeria, Nsukka, Enugu State, Nigeria
}

\begin{abstract}
Crayfish, lobster, and sea-water samples collected from five fishing islands on the Atlantic coast-Bight of Biafra (Bonny)-belonging to Ibaka Local Government Area of Akwa-Ibom State of Nigeria were bacteriologically evaluated on thiosulphate citrate bile-salt sucrose (TCBS) agar for Vibrio load and pathotypes. Mean $\log _{10}$ Vibrio counts of $7.64 \pm 2.78 \mathrm{cfu} / \mathrm{g}$ (in crayfish), $5.07 \pm 3.21 \mathrm{cfu} / \mathrm{g}$ (in lobster), and $3.06 \pm 2.27 \mathrm{cfu} / \mathrm{mL}$ (in sea-water) were obtained in rainy season (June-July) while counts in the dry season (November-December) were $6.25 \pm 1.93 \mathrm{cfu} / \mathrm{g}, 5.99 \pm 1.54 \mathrm{cfu} / \mathrm{g}$, and $3.84 \pm 1.78 \mathrm{cfu} / \mathrm{mL}$ respectively. The physicochemical measurements (temperature, $\mathrm{pH}$, and total dissolved solutes) of the sea-water did not vary significantly in the two seasons across all five islands. Vibrio species isolated were Vibrio cholerae (both $\mathrm{O} 1$ and non-O1 serotypes), $V$. parahaemolyticus, V. vulnificus, V. mimicus, and V. fluvialis. Both Ogawa and Inaba subtypes of $V$. cholerae O1 serotype were found. In addition, the Hikojima subtype, which had not been previously reported in the region, was isolated in two samples. The results show that these Vibrio species are endemic in the area.
\end{abstract}

Key words: Atlantic coastline; Cholera, Vibrio; Hikojima; Sea-water; Shellfish; Nigeria

\section{INTRODUCTION}

The interest in Vibrio species worldwide stems from the history and epidemiology of cholera, a severe diarrhoeal disease thought to have originated from the Far East (Asia) thousands of years ago. The spread of cholera was sea-borne at first, affecting particularly coastal towns and fishing villages. As it gained foothold within the regions, the tribal behaviours of the populations, including funeral ceremonies, movement of people within and between countries, and the use of rivers for transportation, trade, and travel as well as source of domestic water became important factors in the dissemination of the disease on a scale reminiscent of the $19^{\text {th }}$ century pandemics $(1,2)$.

The long-distance spread of the disease to Europe and the Americas through the Middle East region is thought to have begun in 1817. The Ogawa se-

Correspondence and reprint requests:

Dr. Christian U. Iroegbu

Epidemiological Research Unit

Department of Microbiology

University of Nigeria

Nsukka, Enugu State

Nigeria

Email: chrisuiroegbu@yahoo.com rotype is reported to have arrived at the Atlantic coast of West Africa in 1868 when the first cholera outbreak was reported in the region $(3,4)$. From September 1970, the disease invaded West African countries one after another-Guinea and Sierra Leone (28 September 1970), Liberia (October 1970), Ivory Coast (20 October 1970), Mali and Togo (both on 24 November 1970), Dahomey (16 December 1970), Upper Volta (Burkina Faso) (17 December 1970), Nigeria and Niger (27 December 1970) $(1,5)$. The first recorded outbreak of the disease in Nigeria in 1970 was in Lagos, with three bacteriologically-confirmed cases. Since then cholera cases have been reported in various parts of the country $(6,7)$.

Vibrio cholerae, the causative organism of cholera, is just one of over 33 species described in the genus $\mathrm{Vi-}$ brio, among which 12 species, including V. cholerae, have been reported to be pathogenic to humans. Nine of these have actually been isolated in clinical conditions attributed to them (8); 8 among them have been associated with food-borne infections of the gastrointestinal tract (9). Infections due to food-borne Vibrio are common in Asia, including Hong Kong, and in sub-Saharan Africa, including Nigeria $(6,7,10)$. Sea-foods and water are the major 
sources of infection, and Vibrio species have largely been isolated from these sources in the southeastern region of Nigeria $(7,11,12)$. It is against this background that shellfish and water samples from five fishing islands in this region, which are the major sources of shellfish sold in inland markets of Nigeria, were screened for Vibrio species and pathotypes.

\section{MATERIALS AND METHODS}

\section{Description of the project area}

The study was carried out around five fishing islands-Asia-Obufa, Obio-Iwang, Ikot-Itie-Idung, Utam-Iyata, Utam-Antai located on the Bight of Biafra (Bonny) and belonging to Ibaka LGA of AkwaIbom State, Nigeria. Each island has 1,000-1,500 inhabitants. All inhabitants have homes in villages in the mainland and stay in make-shift shelters with their families to engage in daily out-sea fishing activities and shellfish processing for dispatch to the inland markets. The inhabitants have no toilet facilities and defaecate at the banks or inside the sea.

\section{Collection of shellfish and water samples}

Freshly-harvested crayfish and lobsters were purchased from fishermen as they came ashore after the night-fishing activities. These were immediately put in sterile polythene bags to avoid further contamination and conveyed to the laboratory sandwiched between ice-blocks in insulated ice-boxes.

Three sea-water samples (250 $\mathrm{mL}$ each) were also collected from each of the five islands as follows: using a sterilized conical flask, the sea-water samples were collected at 3 points in each island-one just at the ocean bank, the second at about $100 \mathrm{~m}$ from the shore, and the third at about $500 \mathrm{~m}$ from the shore into the sea. The conical flask was held with its mouth down and, in that position, it was submerged into depth of about $100 \mathrm{~cm}$ before the mouth was turned upwards under water to fill. All water samples were transported to the laboratory under the prevailing atmospheric conditions. Estimation of Vibrio cell count of crayfish,
lobsters, and water

\section{Crayfish and lobster}

Approximately $2.0 \mathrm{~g}$ of crayfish or lobster sample was taken and homogenized into smooth slurry, using a sterile pestle and mortar; $1.0 \mathrm{~g}$ of the homogenate was suspended first in $1.0 \mathrm{~mL}$ of normal saline in a $25-\mathrm{mL}$ Pyrex test tube and the volume made up to $10 \mathrm{~mL}$ with more saline to obtain a
$1 \%(\mathrm{w} / \mathrm{v})$ suspension. Subsequently, the suspension of homogenized tissue was serially diluted 10 -fold, down to $10^{-6}$; then, $1.0 \mathrm{~mL}$ of each dilution was spread over a freshly-prepared thiosulphate citrate bile-salt sucrose (TCBS) agar (Oxoid) plate, using a sterile bent glass-rod. The plate was incubated at $37^{\circ} \mathrm{C}$ in a humidified incubator for 24 hours. Triplicate plates were prepared in the same way from a separate $2.0 \mathrm{~g}$ sample of the same batch of crayfish or lobster. After 24 hours, the incubated plates were observed for characteristic Vibrio colonies. Each colony, distinguished mainly by colour and size, was counted separately. Then, discrete representatives of each colony type were randomly selected for purification and characterization.

\section{Water}

Water samples collected from different islands were analyzed for temperature and $\mathrm{pH}$ at the point of collection and for total dissolved solids (TDS), using a TDS meter (Korea, HM Digital Inc.), and values were expressed in parts per million (ppm). Subsequently, approximately $200 \mathrm{~mL}$ of each seawater sample was filtered through a sterile $0.45-\mu \mathrm{m}$ membrane, using a vacuum pump to facilitate the process; then, the filter unit was carefully dismantled, the membrane aseptically removed with sterile forceps and placed on TCBS agar. After incubation at $37^{\circ} \mathrm{C}$ for 24 hours, the plate was examined for characteristic Vibrio colonies which were then counted and discrete colonies randomly selected for characterization.

Characterization of isolates suspected to be Vibrio

The randomly-selected colonies were first Gramstained to ascertain the curved rod cell morphology of Vibrio species before purification by three successive streaking and re-isolations on TCBS agar. The purified isolates were cultured on nutrient agar slants and stored at $4{ }^{\circ} \mathrm{C}$. From the stock culture, each isolate was assayed for oxidase, urease and indole production, motility, and fermentation of various sugars, using the method described by Cheesbrough (13). All isolates preliminarily identified to be Vibrio cholerae from the above assay results were serologically tested for agglutination with polyvalent O1 antiserum (ANTEC, UK). Isolates which tested positive with polyvalent $\mathrm{O} 1$ antiserum were further tested with anti-Ogawa and or anti-Inaba sera to differentiate them into subtypes.

\section{RESULTS}

Vibrio colonies on TCBS agar appeared either yellow (showing that they are sucrose fermenters) 
or green or bluish-green (meaning non-sucrose fermenters). Random microscopy of not less than 50 of each colony morphology type showed that they were predominantly curved or coma-shaped Gram-negative rods, thus confirming that they were Vibrio strains. With this, Vibrio counts were obtained from crayfish, lobster, and water samples collected from all five islands in both rainy season (June-July 2009) and the dry season (NovemberDecember 2009) as shown in Table 1. The $\log _{10}$ mean Vibrio counts (cfu/g) were 7.64 \pm 2.78 (with range $6.29 \pm 3.82-9.26 \pm 4.42$ ) for crayfish, $5.07 \pm 3.21$ (range: $3.11 \pm 1.08-7.37 \pm 1.00$ ) for lobsters, and $3.06 \pm 2.27 \mathrm{cfu} / \mathrm{mL}$ (range: $1.12 \pm 6.12-7.00 \pm 1.20$ ) for sea-water in the rainy season. The values obtained for similar samples in the dry season were $6.25 \pm 1.93$ (range: $5.03 \pm 1.81-8.00 \pm 0.21$ ), $5.99 \pm 1.54$ (range: $4.13 \pm 1.13-9.25 \pm 1.30$ ) and $3.84 \pm 1.78$ (range: $0.15 \pm 2.71-9.11 \pm 1.60$ ) respectively. Water samples were collected from each Island starting at the bank, $100 \mathrm{~m}$, and $500 \mathrm{~m}$ from the beach into the sea; the mean $\log _{10}$ Vibrio counts obtained were $3.84 \pm 1.76 \mathrm{cfu} / \mathrm{mL}$ (range: $0.15 \pm 2.71-9.11 \pm 1.60$ ), $4.42 \pm 1.61$ (range: $1.98 \pm 3.31-7.45 \pm 1.00$ ), and $5.66 \pm 1.12 \mathrm{cfu} / \mathrm{mL}$ (range: $4.19 \pm 1.41-8.01 \pm 1.11$ ) respectively (Table 2).

Further characterization of the colony morphology types showed that the yellow colonies (sucrose fer- menters) were predominantly either $V$. cholerae or $V$. fluvialis while the non-sucrose fermenters were either $V$. parahaemolyticus, $V$. mimicus, or $V$. vulnificus. All five Vibrio species were isolated from crayfish and lobster samples screened from each of the five islands with the frequencies shown in Table 3 and 4 in both rainy (June-July) and dry (November-December) seasons. The differences in frequency of isolation of species from different islands and in the two seasons were not statistically significant $(\mathrm{p}>0.05)$. Table 5 shows proportions of the Vibrio cholerae isolates obtained from the shellfish and water samples that were $\mathrm{O} 1$ and non-O1 serotypes from each of the five islands both in the rainy season and in the dry season. With the exception of the crayfish samples of rainy season and the water samples (obtained both in rainy and dry seasons) in which there were preponderance of $V$. cholerae $\mathrm{O} 1$ serotypes over the non-O1 strains, the relative occurrence of each serotype varied with locations. The Inaba and Ogawa subtypes of the $V$. cholerae $\mathrm{O} 1$ serotype were found in all locations in both shellfish and water samples. The Hikojima subtype was isolated only twice.

The physicochemical analyses of sea-water from locations in the five islands showed that the temperatures ranged between $27^{\circ} \mathrm{C}$ and $28^{\circ} \mathrm{C}$ in the rainy season (June-July) and was $28^{\circ} \mathrm{C}$ allover in the dry season (November-December). The $\mathrm{pH}$

\begin{tabular}{|c|c|c|c|c|c|c|}
\hline \multirow{3}{*}{$\begin{array}{l}\text { Island/Source } \\
\text { of the samples }\end{array}$} & \multicolumn{6}{|c|}{$\log _{10}$ mean Vibrio count \pm standard deviation (SD) } \\
\hline & \multicolumn{3}{|c|}{ Rainy season } & \multicolumn{3}{|c|}{ Dry season } \\
\hline & Crayfish & Lobster & Water & Crayfish & Lobster & Water \\
\hline Asia-Obufa & $6.29 \pm 3.82$ & $4.32 \pm 9.23$ & $2.08 \pm 2.51$ & $7.16 \pm 1.90$ & $9.25 \pm 1.30$ & $4.51 \pm 1.60$ \\
\hline Obio-Iwang & $7.12 \pm 2.32$ & $5.73 \pm 3.13$ & $7.00 \pm 1.20$ & $5.27 \pm 1.52$ & $4.13 \pm 1.13$ & $9.11 \pm 1.60$ \\
\hline Ikot-Itie-Idung & $8.10 \pm 2.11$ & $7.37 \pm 1.00$ & $1.92 \pm 0.52$ & $5.81 \pm 4.20$ & $6.00 \pm 2.13$ & $3.11 \pm 1.15$ \\
\hline Utam-Iyata & $9.26 \pm 4.42$ & $4.80 \pm 1.63$ & $3.17 \pm 1.00$ & $5.03 \pm 1.81$ & $6.41 \pm 1.12$ & $2.31 \pm 1.82$ \\
\hline Utam-Antai & $7.41 \pm 1.22$ & $3.11 \pm 1.08$ & $1.12 \pm 6.12$ & $8.00 \pm 0.21$ & $4.17 \pm 2.00$ & $0.15 \pm 2.71$ \\
\hline Total average & $7.64 \pm 2.78$ & $5.07 \pm 3.21$ & $3.06 \pm 2.27$ & $6.25 \pm 1.93$ & $5.99 \pm 1.54$ & $3.84 \pm 1.78$ \\
\hline
\end{tabular}

\begin{tabular}{|lcccc|}
\hline \multicolumn{4}{l}{ Table 2. Distribution of Vibrio counts in water collected at different distances (metres) from the beach } \\
\hline $\begin{array}{l}\text { Island/Source of } \\
\text { samples }\end{array}$ & $\begin{array}{l}\log _{10} \text { Vibrio count in water collected at different } \\
\text { distances }(\mathrm{m}) \text { from the beach }\end{array}$ & $\begin{array}{c}\log _{10} \text { mean Vibrio } \\
\text { count } \pm S D\end{array}$ \\
\cline { 2 - 4 } & 0 & 100 & 500 & \\
\hline Asia-Obufa & $4.51 \pm 1.60$ & $4.90 \pm 0.25$ & $5.18 \pm 0.33$ & $4.86 \pm 0.73$ \\
Obio-Iwang & $9.11 \pm 1.60$ & $1.98 \pm 3.31$ & $5.77 \pm 1.22$ & $5.62 \pm 2.04$ \\
Ikot-Itie-Idung & $3.11 \pm 1.15$ & $7.45 \pm 1.00$ & $8.01 \pm 1.11$ & $6.19 \pm 1.09$ \\
Utam-Iyata & $2.31 \pm 1.82$ & $3.50 \pm 0.18$ & $5.13 \pm 1.55$ & $3.65 \pm 1.18$ \\
Utam-Antai & $0.15 \pm 2.71$ & $4.27 \pm 3.31$ & $4.19 \pm 1.41$ & $2.87 \pm 2.47$ \\
\hline Log $_{10}$ mean count \pm SD & $3.84 \pm 1.78$ & $4.42 \pm 1.61$ & $5.66 \pm 1.12$ & $4.64 \pm 1.50$ \\
\hline
\end{tabular}




\begin{tabular}{|c|c|c|c|c|c|c|}
\hline \multirow{2}{*}{$\begin{array}{l}\text { Island/Source of } \\
\text { samples }\end{array}$} & \multirow{2}{*}{$\begin{array}{l}\text { No. of } \\
\text { isolates }\end{array}$} & \multicolumn{5}{|c|}{ Distribution of Vibrio species (\%) } \\
\hline & & $\begin{array}{l}\text { Vibrio } \\
\text { cholerae }\end{array}$ & $\begin{array}{c}\text { Vibrio } \\
\text { fluvialis }\end{array}$ & $\begin{array}{c}\text { Vibrio } \\
\text { mimicus }\end{array}$ & $\begin{array}{l}\text { Vibrio para- } \\
\text { haemolyticus }\end{array}$ & $\begin{array}{c}\text { Vibrio } \\
\text { vulnificus }\end{array}$ \\
\hline \multicolumn{7}{|c|}{ Rainy season } \\
\hline Asia-Obufa & 137 & $39(28.47)$ & $23(16.79)$ & $12(8.76)$ & $36(26.28)$ & $27(19.71)$ \\
\hline Obio-Iwang & 124 & $26(20.97)$ & $31(25.00)$ & $24(19.35)$ & $28(22.58)$ & $15(12.10)$ \\
\hline Ikot-Itie-Idung & 138 & $23(16.67)$ & 19 (13.77) & $39(28.26)$ & $31(22.46)$ & $26(18.84)$ \\
\hline Utam-Iyata & 128 & $33(26.61)$ & $28(22.58)$ & $24(19.35)$ & $28(22.58)$ & $15(12.10)$ \\
\hline Utam-Antai & 143 & $21(14.69)$ & $28(19.58)$ & $31(21.68)$ & $34(23.78)$ & $29(20.28)$ \\
\hline \multicolumn{7}{|c|}{ Dry season } \\
\hline Asia-Obufa & 149 & $21(14.09)$ & $40(26.85)$ & $30(20.13)$ & $31(20.81)$ & $17(18.12)$ \\
\hline Obio-Iwang & 135 & $23(17.04)$ & $19(14.07)$ & $37(27.41)$ & 35 (25.93) & $21(15.56)$ \\
\hline Ikot-Itie-Idung & 145 & $21(14.48)$ & $28(19.31)$ & $35(24.14)$ & $41(28.28)$ & $20(13.79)$ \\
\hline Utam-Iyata & 159 & $26(16.35)$ & $32(20.13)$ & 37 (23.27) & 38 (23.90) & $26(16.35)$ \\
\hline Utam-Antai & 168 & 37 (16.07) & $35(20.83)$ & $38(22.62)$ & 39 (23.21) & $29(17.26)$ \\
\hline Total & 1,426 & 270 & 283 & 307 & 341 & 225 \\
\hline
\end{tabular}

Table 4. Frequency of isolation of Vibrio species from lobster samples collected from the five islands during the rainy and dry seasons

\begin{tabular}{|c|c|c|c|c|c|c|}
\hline \multirow[b]{2}{*}{$\begin{array}{l}\text { Island/Source of } \\
\text { samples }\end{array}$} & \multirow[b]{2}{*}{$\begin{array}{l}\text { No. of } \\
\text { isolates }\end{array}$} & \multicolumn{5}{|c|}{ Distribution of Vibrio species (\%) } \\
\hline & & $\begin{array}{c}\text { Vibrio } \\
\text { cholerae }\end{array}$ & $\begin{array}{l}\text { Vibrio } \\
\text { fluvialis }\end{array}$ & Vibrio mimicus & $\begin{array}{l}\text { Vibrio para- } \\
\text { haemolyticus }\end{array}$ & $\begin{array}{c}\text { Vibrio } \\
\text { vulnificus }\end{array}$ \\
\hline \multicolumn{7}{|c|}{ Rainy season } \\
\hline Asia-Obufa & 129 & $28(21.71)$ & $31(24.03)$ & $19(14.73)$ & $22(17.05)$ & $29(22.48)$ \\
\hline Obio-Iwang & 122 & $30(24.59)$ & $17(13.93)$ & $26(21.31)$ & $27(22.13)$ & $22(18.03)$ \\
\hline Ikot-Itie-Idung & 132 & $19(14.39)$ & $23(17.42)$ & $32(24.24)$ & $29(21.97)$ & $29(21.97)$ \\
\hline Utam-Iyata & 122 & $30(24.59)$ & $17(13.93)$ & $26(21.31)$ & $27(22.13)$ & $22(18.03)$ \\
\hline Utam-Antai & 133 & $29(21.80)$ & $30(22.56)$ & $26(19.55)$ & $31(23.31)$ & $17(12.78)$ \\
\hline \multicolumn{7}{|c|}{ Dry season } \\
\hline Asia-Obufa & 138 & $36(26.08)$ & $22(15.94)$ & $28(20.29)$ & $19(13.77)$ & $33(23.91)$ \\
\hline Obio-Iwang & 124 & $26(20.97)$ & $23(18.55)$ & $28(22.58)$ & $28(22.58)$ & $19(15.32)$ \\
\hline Ikot-Itie-Idung & 135 & $19(14.07)$ & $31(22.96)$ & $30(22.22)$ & $29(21.48)$ & $26(19.26)$ \\
\hline Utam-Iyata & 146 & 34 (23.29) & $24(16.44)$ & $31(21.23)$ & $33(22.60)$ & $24(16.44)$ \\
\hline Utam-Antai & 157 & $31(19.75)$ & $27(17.20)$ & $41(26.11)$ & 37 (23.57) & 21 (13.38) \\
\hline Total & 1,338 & 282 & 245 & 287 & 282 & 242 \\
\hline
\end{tabular}

ranges were 7.4-7.6 (rainy season) and 7.5-7.6 (dry season) while the total dissolved solutes (TDS) measured 155-164 ppm in rainy season and 155-165 ppm in dry season (Table 6).

\section{DISCUSSION}

The shellfish (crayfish and lobster) harvested from waters of the Atlantic coast were heavily contaminated with Vibrio species; Vibrio counts were estimated to be as high as $10^{4}-10^{9} \mathrm{cfu} / \mathrm{g}$, much higher than the counts recorded by Chigbu and Iroegbu (7). Samples of the water habitat from where the shellfish was harvested were equally heavily contaminated with Vibrio counts reaching $10^{7}-10^{9} \mathrm{cfu} /$ $\mathrm{mL}$ in some places. This could be assumed to be the natural source of shellfish contamination. This does not preclude the chances of the crayfish and lobsters concentrating the Vibrio cells as filter feeders (14). Human agencies, including direct daefecation into the sea and faecally-contaminated surface water running into the sea (prevalent in the area) 


\begin{tabular}{|c|c|c|c|c|c|c|c|c|c|}
\hline \multirow{3}{*}{$\begin{array}{l}\text { Island/Source of } \\
\text { samples }\end{array}$} & \multicolumn{9}{|c|}{ Frequency of isolation of Vibrio cholerae serotypes } \\
\hline & \multicolumn{3}{|c|}{ Crayfish } & \multicolumn{3}{|c|}{ Lobster } & \multicolumn{3}{|c|}{ Water } \\
\hline & $\begin{array}{c}\text { No. } \\
\text { isolated }\end{array}$ & O1 & Non-O1 & $\begin{array}{c}\text { No. } \\
\text { isolated }\end{array}$ & $\mathrm{O} 1$ & Non-O1 & $\begin{array}{c}\text { No. } \\
\text { isolated }\end{array}$ & $\mathrm{O} 1$ & Non-O1 \\
\hline \multicolumn{10}{|c|}{ Rainy season } \\
\hline Asia-Obufa & 39 & 32 & 7 & 28 & 27 & 1 & 13 & 11 & 2 \\
\hline Obio-Iwang & 26 & 23 & 3 & 30 & 11 & 19 & 17 & 8 & 9 \\
\hline Ikot-Itie-Idung & 23 & 23 & 0 & 19 & 16 & 3 & 14 & 7 & 7 \\
\hline Utam-Iyata & 33 & 27 & 6 & 30 & 13 & 17 & 15 & 10 & 5 \\
\hline Utam-Antai & 21 & 16 & 5 & 29 & 11 & 18 & 8 & 7 & 1 \\
\hline \multicolumn{10}{|c|}{ Dry season } \\
\hline Asia-Obufa & 21 & 15 & 6 & 36 & 19 & 17 & 16 & 13 & 3 \\
\hline Obio-Iwang & 23 & 6 & 17 & 26 & 4 & 22 & 13 & 8 & 5 \\
\hline Ikot-Itie-Idung & 21 & 9 & 12 & 19 & 17 & 2 & 15 & 11 & 4 \\
\hline Utam-Iyata & 26 & 18 & 8 & 34 & 19 & 15 & 16 & 14 & 2 \\
\hline Utam-Antai & 27 & 7 & 20 & 31 & 13 & 18 & 13 & 12 & 1 \\
\hline
\end{tabular}

Table 6. Physicochemical properties of sea-water from each study area/island

\begin{tabular}{llccccccc}
\multirow{2}{*}{$\begin{array}{l}\text { Island/Source of } \\
\text { samples }\end{array}$} & \multicolumn{3}{c}{ Rainy season (June-July) } & & \multicolumn{3}{c}{ Dry season (November-December) } \\
\cline { 2 - 4 } & $\mathrm{pH}$ & Temp. $\left({ }^{\circ} \mathrm{C}\right)$ & $\mathrm{TDS}(\mathrm{ppm})$ & & $\mathrm{pH}$ & Temp. $\left({ }^{\circ} \mathrm{C}\right)$ & $\mathrm{TDS}(\mathrm{ppm})$ \\
\hline Asia-Obufa & 7.6 & 27 & 158 & & 7.6 & 28 & 155 \\
Obio-Iwang & 7.4 & 28 & 163 & & 7.6 & 28 & 165 \\
Ikot-Itie-Idung & 7.3 & 28 & 158 & & 7.5 & 28 & 160 \\
Utam-Iyata & 7.5 & 27 & 155 & & 7.6 & 28 & 158 \\
Utam-Antai & 7.6 & 28 & 164 & & 7.6 & 28 & 165 \\
\hline TDS=Total dissolved solids & & & & & & \\
\hline
\end{tabular}

could be the main contributors to contamination of the sea-water itself. Direct defaecation into the sea or river was less apparent in the locations researched by Chigbu and Iroegbu (7) and could account for the wide differences in Vibrio counts obtained in both studies.

All five Vibrio species isolated from shellfish and sea-water of the Atlantic coast of South-Eastern Nigeria are known to be pathogenic to humans. Vibrio cholerae and V. parahaemolyticus certainly, but $V$. fluvialis and V. mimicus also, have been associated with gastroenteritis or diarrhoeal diseases. Vibrio vulnificus, on the other hand, has been associated with wound infection and has been mentioned in connection with bathing in the sea and handling of fish and other sea-foods. Thus, isolation of all the five pathogenic Vibrio species from sea-water and shellfish harvested from this habitat is of great public and environmental health significance, given that members of the fishing communities have a culture of eating the shellfish raw, handling sea- food harvests, and swimming in the sea. It is interesting to note that Chigbu and Iroegbu (7), working in the same region but in different locations, encountered only $V$. cholerae, $V$. parahahaemolyticus (also isolated in this study), and $V$. alginolyticus (not isolated in this study). The main difference in the two studies is that the earlier work was carried out around the Cross River estuary (around Calabar city) and in Ikom, more than $200 \mathrm{~km}$ from the Atlantic coastline where environmental samples were drawn from freshwater sources; the study reported here was carried out in islands located far into the sea and where human activity was constantly within the water environment. It is likely that such human activity may have influenced both Vibrio counts and the variety of Vibrio species.

Among the five Vibrio species isolated, Vibrio cholerae is the recognized benchmark of Vibrio pathogenicity, and it is based on what was earlier known about the epidemiology of this species that dates back to 1883 through the early 1980s. It was as- 
sumed that the human intestine was the sole reservoir of $V$. cholerae and that the organism was incapable of surviving for long in water. It was, therefore, held that infection had to be due to recent faecal contamination of drinking-water and foods. In the same thinking, humans have been thought to be the source of contamination of the sea-water and sea-foods (as mentioned earlier). This is buttressed by the culture of direct defaecation into the sea-water, a culture that prevails among fishing communities in the five islands sampled (Eyisi, personal observation). It was, however, later observed that $V$. cholerae exhibited a capacity of entering a rest-period during adverse environmental conditions (15-17). This changed all the earlier hypotheses; $V$. cholerae can apparently survive in marine waters, frequently associated with phytoor zoo-plankton, for several months. During seasons, when the temperatures and abundance of nutrients favour bloom of planktons, the bacteria multiply greatly $(18,19)$. This does not contradict the fact that faecally-contaminated drinking-water constitutes the main source of infection with $V$. cholerae; the water then contaminates sea-foods as earlier posited. This sufficiently explains the muchreported relative abundance of the organisms with increase in temperature (20), such as during the dry season in the tropical regions of the world (7) or the warm summer months (21). In this work, Vibrio counts did not vary significantly between the dry and rainy seasons, and this may just be explained by the fairly uniform temperatures, $\mathrm{pH}$, and dissolved solutes observed around all five islands in both the seasons. The uniform physicochemical conditions in the two seasons would be expected at about latitude $4{ }^{\circ} \mathrm{N}$ (above the equator) where the investigation was carried out. Besides, the dry season (November-December) sampling included the cool harmattan month of December, very close to the time the region may experience the last rains (early October). There may not have been enough time for a significant change in the water temperatures, $\mathrm{pH}$, and nutrient concentrations (for the bloom of planktons).

Both $\mathrm{O} 1$ and non-O1 serotypes of $V$. cholerae were isolated from water and shellfish samples with the O1 serotype predominant at times. The latter observation was unexpected, given that in environmental samples like the ones analyzed in this work, non-O1 serotype is expected to be more abundant. The possible explanation for this unexpected distribution pattern may be that much of the O1 serotype is constantly seeded into the water environment from human sources; and the shellfish pick the Vibrio contaminants, particularly the $\mathrm{O} 1$ serotype, from the water environment. This has a further public-health implication in the area-the risk of disseminating the pathogen(s) to the inland fish markets through the contaminated harvests (processed and unprocessed).

Only the Vibrio $\mathrm{O} 1$ serotypes were further tested to determine the subtypes present. The Ogawa and Inaba subtypes were abundantly isolated. These have largely been reported even in epidemic cholera along the West coast of Africa and in South-Eastern Nigeria in particular $(7,11,12)$. It is significant that Hikojima subtype was isolated in two locations in this work. This is probably the first time the Hikojima subtype has been reported in Nigeria. It is not certain whether this subtype got to the West African coastline from Asia as well or it genetically arose in habitat as intermediate between the Ogawa and Inaba subtypes here in the West African or Nigerian coastal waters.

\section{ACKNOWLEDGEMENTS}

We wish to thank the community heads of the five islands for their hospitality and help when Onyedikachi Eyisi and Uche Nwodo visited to collect samples, particularly Chief Akpate of Asia Obufa Island who provided accommodation for them. We also thank their guide and interpreter Odua Godwin Etim who gave them courage to travel to the islands in speedboat in the open sea.

\section{REFERENCES}

1. Kamal AM. The seventh pandemic of cholera. In: Barua D, Burrows W, editors. Cholera. Philadelphia, PA: Saunders, 1974:1-14.

2. Barbieri E, Falzano L, Fiorentini C, Pianetti A, Baffone W, Fabbri A et al. Occurrence, diversity, and pathogenicity of halophilic Vibrio spp. and non-O1 Vibrio cholerae from estuarine waters along the Italian Adriatic coast. Appl Environ Microbiol 1999;65:2748-53.

3. Macnamara NC. A history of Asiatic cholera. London: Macmillan, 1876:340.

4. Varnam AH, Evans MG. Foodborne pathogens: an illustrated text. Philadelphia, PA: Mosby, 1991:174-7.

5. Bockemühl J, Triemer A. Ecology and epidemiology of Vibrio parahaemolyticus on the coast of Togo. Bull World Health Organ 1974;5:353-60.

6. Eko FO, Udo SM, Antia-Obong OE. Epidemiology and spectrum of Vibrio diarrheas in the lower cross river basin of Nigeria. Cent Eur J Public Health 1994;2:37-41.

7. Chigbu LN, Iroegbu CU. Vibrio species from diarrhoeal stools and water environment in Cross River State, Nigeria. Int J Environ Health Res 2000;10:219-28. 
8. Janda JM, Bryant RG. Pathogenic Vibrio spp.: an organism group of increasing medical significance. Clin Microbiol Newsl 1987;9:49-53.

9. Oliver JD, Kaper JB. Vibrio species. In: Doyle MP, Beuchat IR, Montville TJ, editors. Food microbiology: fundamentals and frontiers. Washington, DC: American Society for Microbiology Press, 2001:263-300.

10. Sutherland J, Varnam A. Enterotoxin-producing Staphylococcus, Shigella, Yersinia, Vibrio, Aeromonas and Plesiomonas. In: de W Blackburn C, McClure PJ, editors. Foodborne pathogens: hazards, risk analysis and control. Cambridge: Woodhead Publishing, 2002:385-415.

11. Utsalo SJ, Mboto CI, Gemade EII, Nwangwa MA. Halophilic Vibrio spp. associated with hard clams (Mercenaria spp.) from the Calabar river estuary. Trans R Soc Trop Med Hyg 1988;82:327-9.

12. Eko FO, Udo SM, Antia-Obong OE. Epidemiology and spectrum of Vibrio diarrheas in the lower cross river basin of Nigeria. Cent Eur J Public Health 1994;2:37-41.

13. Cheesbrough M. District laboratory practice in tropical countries. Part 2. 2nd ed. Cambridge: Cambridge University Press, 2006:62-7.

14. Watkins W, McCarthy S, editors. Proceedings of the 1994 Vibrio vulnificus workshop. Washington, DC: US Department of Health and Human Services, 1994. 175 p.
15. Oliver JD. The viable but nonculturable state and cellular resuscitation. In: Bell CR, Brylinsky M, JohnsonGreen P, editors. Microbial biosystems: new frontiers. Halifax: Atlantic Canada Society for Microbial Ecology, 2000:723-30.

16. Oliver JD, Dagher M, Linden K. Induction of Escherichia coli and Salmonella typhimurium into the viable but nonculturable state following chlorination of wastewater. J Water Health 2005;3:249-57.

17. Colwell RR, Seidler RJ, Kaper J, Joseph SW, Garges S, Lockman $\mathrm{H}$ et al. Occurrence of Vibrio cholerae serotype 01 in Maryland and Louisiana estuaries. Appl Environ Microbiol 1981;41:555-8.

18. Lipp EK, Huq A, Colwell RR. Effects of global climate on infectious disease: the cholera model. Clin Microbiol Rev 2002;15:757-70.

19. de Magny GC, Murtuguddeb R, Sapiano MRP, Nizam A, Brown CW, Busalacchib AJ et al. Environmental signatures associated with cholera epidemics. Proc Natl Acad Sci U S A 2008;105:17676-81.

20. Kaspar CW, Tamplin ML. Effects of temperature and salinity on the survival of Vibrio vulnificus in seawater and shellfish. Appl Environ Microbiol 1993;59:2425-9.

21. Bross MH, Soch K, Morales R, Mitchell RB. Vibrio vulnificus infection: diagnosis and treatment. Am Fam Physician 2007;76:539-44. 